\title{
PEMBERIAN VAKSINISASI COVID-19 BAGI IBU HAMIL PADA MASA PANDEMI
}

\author{
Rosidah Solihah, Aulia Ridla Fauzi, Rifa Aulia Aripiani \\ STIKes Muhammadiyah Ciamis
}

\author{
(Korespondensi : rosidahsolihah11@gmail.com)
}

\begin{abstract}
ABSTRAK
Sebaran Coronavirus atau Severeacute respiratory syndrome coronavirus-2 (SARS-CoV-2) sudah mecapai angka 216 juta kasus. Coronavirus disease 2019(COVID-19) adalah penyakit yang menyerang radang pernafasan akut. Angka kematian di Indonesia dari kasus yang terkonfitmasi adalah 131.372. beberapa diantaranya kasus wanita hamil. Perubahan fisiolgis yang terjadi pada wanita hamil menyebabkan dia rentan terkena virus. Untuk itu, diperlukan pencegahan sebaran infeksi pada ibu hamil, salah satunya dengan memberikan vaksin. Namun, pemberian vaksin masih menjadi dilema bagi sebagian kalangan ibu hamil. Rumor tentang efek samping seperti, keguguran dan gangguan kesuburan inilah yang menjadi penyebab sebagain orang menghindari penerimaan vaksinisasi bagi ibu hamil. Tujuan literatur review adalah untuk mengetahui keamanan pemberian vaksinisasi COVID-19 pada ibu hamil. Metodelogi dalam literatur rivew ini adalah dengan mencari jurnal-jurnal terkait pemberian vaksinisasi COVID-19 bagi ibu hamil dengan kata kunci (pregnancy, Vaccines, COVID-19, SARS-CoV-2) pada bulan agustus. Hasil dari tinjauan ini adalah masih belum adanya data konkret tentang keamanan virus COVID-19, meskipun demikian pemberian vaksin COVID-19 dilakukan untuk pencegahan dan perlindungan bagi ibu hamil.Perlu dilakukan lagi penelitian dan uji klinis yang memberikan data konkret terkait keamanannya.
\end{abstract}

Kata kunci : Pregnancy, Vaccines, COVID-19, SARS-Cov-2

\begin{abstract}
ABSTRAK
The spread of the Corona virus or Severeacute respiratory syndrome coronavirus-2 (SARS-CoV-2) has reached 216 million cases. Coronavirus Disease 2019 (COVID-19) is an acute respiratory disease. Indonesia's death toll from confirmed cases is 131,372. some of which are cases of pregnant women. Physiological changes that occur in pregnant women cause themselves to be susceptible to viruses. For this reason, it is necessary to prevent the spread of infection in pregnant women, one of which is by giving vaccines. However, giving the vaccine is still a dilemma for some pregnant women. Rumors about side effects such as infertility and impaired fertility are the reason people avoid vaccinations for pregnant women. The purpose of the literature review is to determine the administration of COVID-19 vaccination to pregnant women. The methodology in this literature review is to search for journals related to the provision of COVID-19 vaccination for pregnant women with keywords (pregnancy, Vaccines, COVID19, SARS-CoV-2) in August. As a result, there is still no concrete data related to the COVID-19 virus, even though the COVID-19 vaccine has been given for prevention and protection for mothers. More research and clinical trials are needed to provide specific data on its safety.
\end{abstract}

Keywords: Pregnancy, Vaccines, COVID-19, SARS-Cov-2

\section{PENDAHULUAN}

Pandemi yang terjadi lebih dari satu tahun ini merupakan penyebab perubahan besarbesaran di seluruh dunia. Bermula dari kota Wuhan Provinsi Huebei, Tiongkok virus itu

awal mula terkonfirmasi. Tanggal 11 Februari 2020, World Health Organization memberi nama virus baru tersebut Severeacute respiratory syndrome coronavirus-2 (SARS-CoV-2) dan 
nama penyakitnya sebagai Coronavirus disease 2019(COVID-19)(WHO,2021).

Severeacute respiratory syndrome coronavirus-2 (SARS-CoV-2) menginfeksi sistem pernafasan, dengan tingkat infeksi yang ringan seperti flu hingga infeksi yang berat seperti infeksi paru-paru (pneumonia). Penyebarannya melalui percikan dahak (droplet) menyebabkan penyebarannya menjadi sangat masif. Sampai artikel ini dibuat total kasus yang terkonfirmasi dari seluruh dunia sebesar 216 juta kasus dengan 4,49 juta kasus kematian yang terkonfirmasi karena infeksi COVID-19 (Wikipedia, 2021). Indonesia sendiri telah mengkonfirmasi 4.066.404 kasus, dengan 131.372 jumlah kasus kematian yang terkonfirmasi (Gugas COVID-19, 2021). kelompok rentan yang berisiko lebih besar, salah satunya adalah ibu hamil (Qiao, 2020). Wanita hamil dengan COVID-19 terjadi pada trimester pertama, kedua, dan ketiga. Infeksi COVID-19 pada ibu hamil dapat memengaruhi organ ogenesis dan perkembangan janin. Semakin dini kasus infeksi, semakin besar pula risiko keguguran (Briet et al, 2020). Wanita hamil dengan COVID-19 lebih mungkin melahirkan secara prematur (studi; 8549 wanita) (WHO, 2021).

Pencegahan dan pengendalian penuluran terhadap ibu hamil perlu dilakukan dengan tepat dan cepat. Vaksinisasi pada ibu hamil kini sudah digalangkan pemerintah. Meskipun beberapa ibu hamil tidak masih dilemma dengan mengadaan vaksin. Pada bulan Desember 2020, sebuah posting blog muncul secara online yang mengklaim, bahwa seorang karyawan senior di Pfizer khawatir bahwa antibodi yang dihasilkan oleh vaksin COVID-19 dapat menyerang plasenta (Male V, 2021). Kabar hoxs itu masih dipercayai oleh sebagian kalangan, terlebih lagi jarangnya keikutsertaan ibu hamil terhadap menelitian dan uji klinis vaksin.

Berdasarkan uraian diatas maka artikel ini disusun untuk mengetahui tingkat keamanan vaksin covid-19 bagi ibu hamil dari berbagai sumber referensi artikel internasional.

\section{METODE}

Penyusunan literatur rivew ini menggunakan metode PRISMA (Preferred Reporting Items for Systematic Reviews and Meta-analyses), mengumpulkan dan menganalisis artikel dan jurnal terkait vaksinisasi covid-19 pada ibu hamil.

Kriteria inklusi artikel literatur ini adalah jurnal internasional dalam kurung waktu 1 tahun terakhir selama terjadinya pandemi covid-19 yang diakses pencarian internet melalui data base. Artikel-artikel ini diperoleh dari ELSIVER 2 jurnal, Pubmed 6 jurnal, scholar jurnal, sciencedirect jurnal

Artikel-artikel ini diperoleh dari scholar, dengan kata kunci (Vaccines, COVID-19, For, Pregnancy) 


\section{Karakteristik Pencarian Literatur}

\section{PEMBAHASAN}

Setelah dilakukan pencarian data melalui basis dalam kriteria inklusi dan ekslusi. Sehingga 6 data yang tersedia ditemukan 13 jurnal terkait jurnal tersebut selanjutnya akan dilakukan pemberian vaksin covid-19 kepada wanita review. Berikut merupakan strategi literatur hamil. Namun, hanya 6 jurnal yang termasuk yang termuat dalam skema di bawah:

Pencarian Literatur:

Basis Data:ELSIVER, Pubmed, Google Scholar

Batasan pencarian: artikel internasional

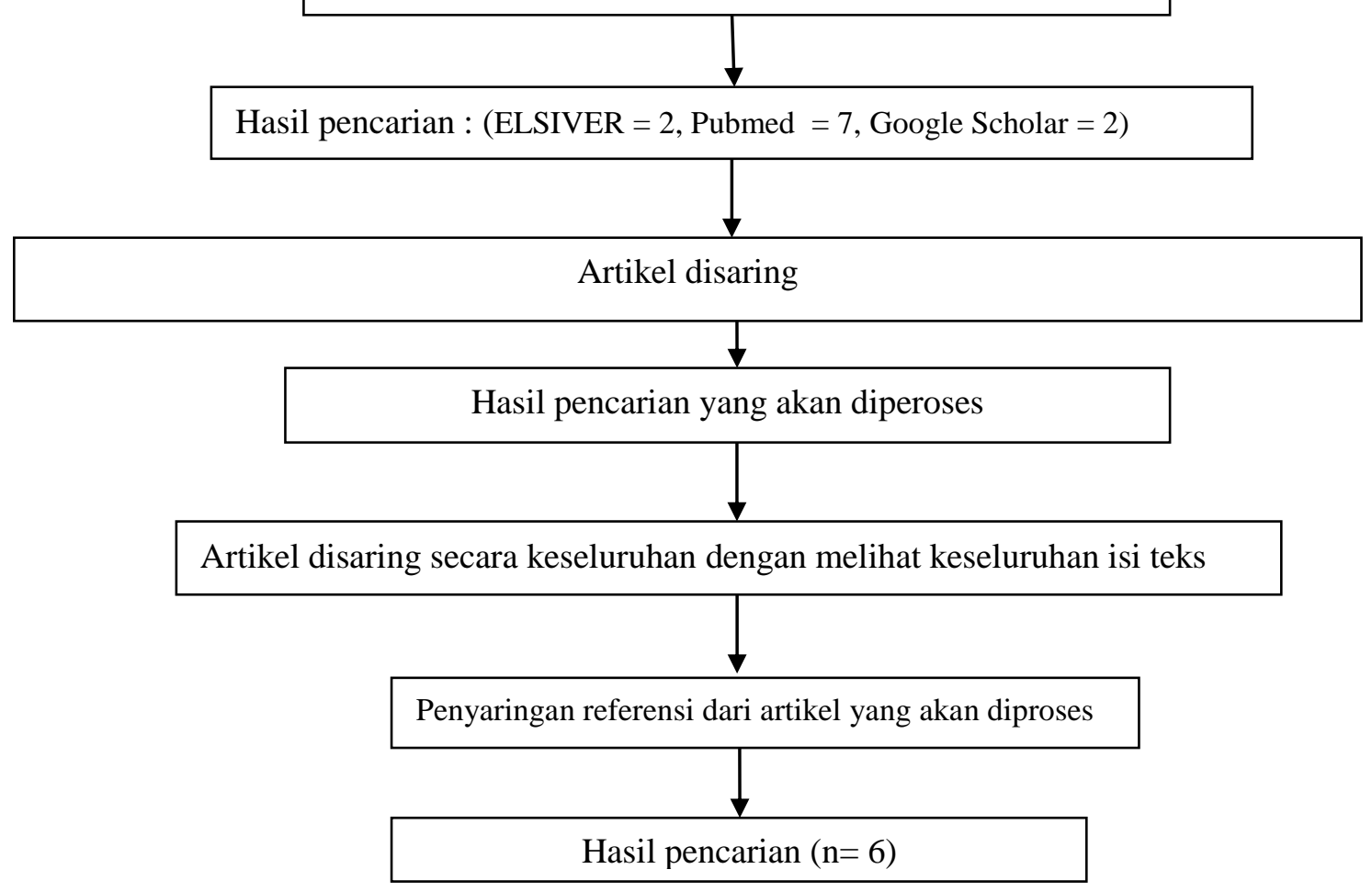

Gambar 1. Tahapan Literatur Review dengan PRISMA 


\section{Analisis Hasil Tinjauan Literatur}

Tabel 1. Ekstraksi Data Literatur

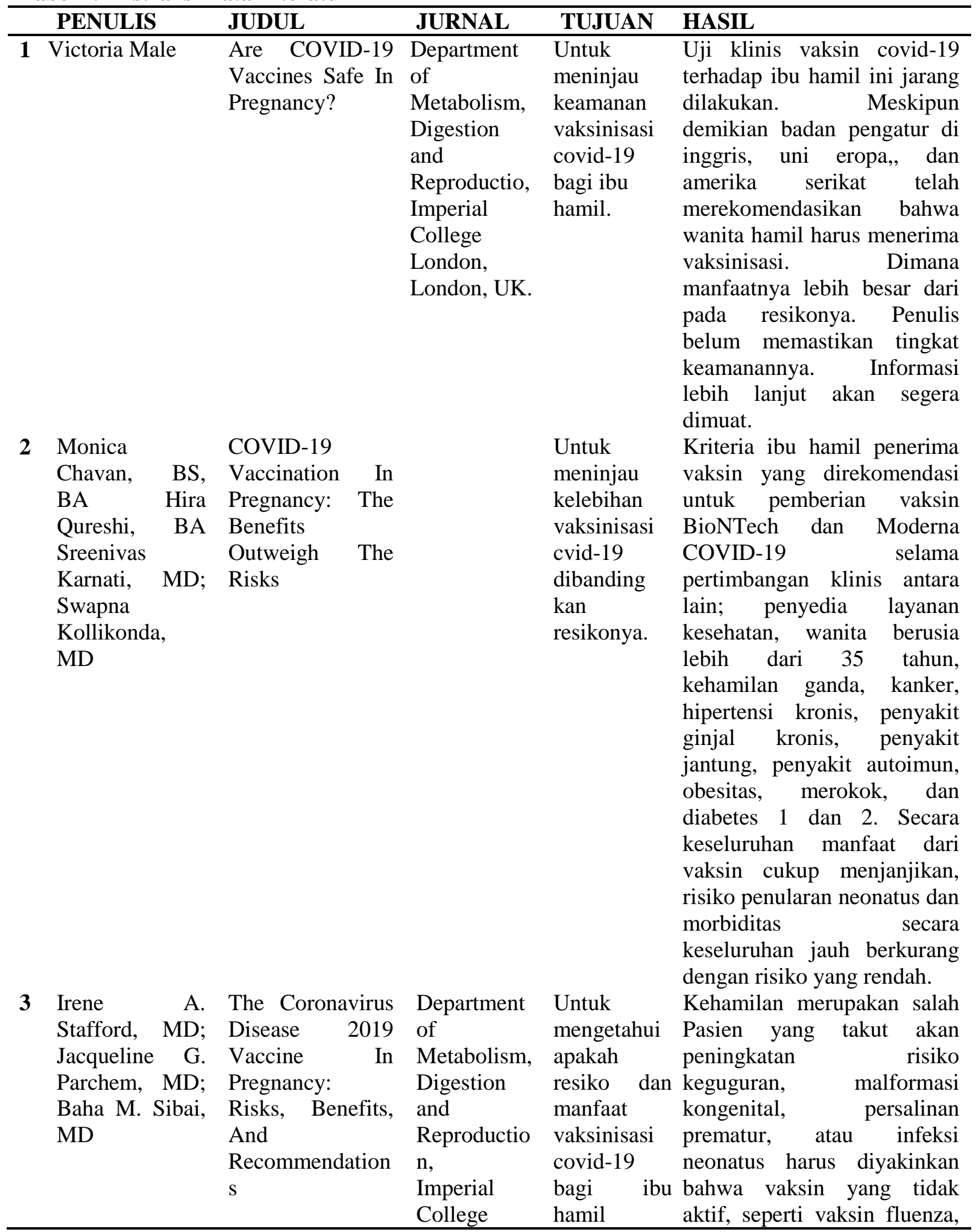




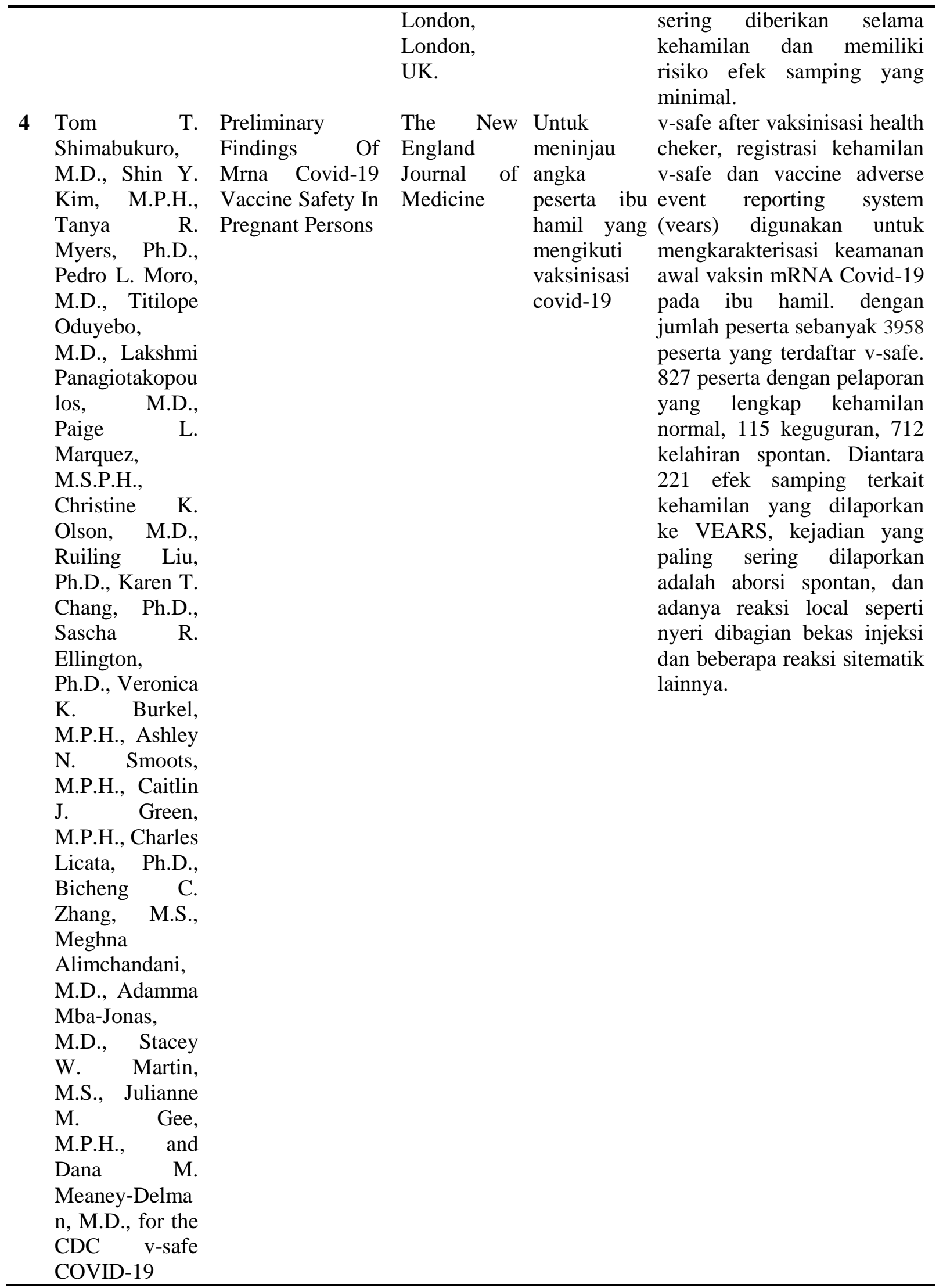


Pregnancy

Registry Team

5 Laura E, Riley, M.D

$\begin{array}{ll}\text { mRNA Covid-19 } & \text { From New } \\ \text { Vaccines In } & \text { York- } \\ \text { Pregnant Women } & \text { Presbyterian } \\ & \text { /Weill } \\ & \text { Cornell } \\ & \text { Medical } \\ & \text { Center and } \\ & \text { Weill } \\ & \text { Cornell } \\ & \text { Medicine, } \\ & \text { New York. }\end{array}$

Untuk Inggris mengeluarkan meninjau otorisasi penggunaan darurat vaksinisas untuk penggunaan vaksin i covid-19 messenger RNA (mrna) mRNA BNT162B2 (Pfizer pada ibu BioNTech) dan mRNA-1273 hamil. (moderna) diberikan untuk orang-orang yang memiliki risiko tinggi terpapar, salah satunya wanita hamil. pada 26 april 2021, lebih dari 100.000 wanita hamil melaporkan telah mengikuti vaksinisasi COVID-19 namun hanya sebgain kecil $(4,7 \%)$ yang telah mendapatr di v-safe untuk mencatat laporan setelah mengikuti vaksinisasi

\begin{tabular}{|c|c|c|c|c|}
\hline $\begin{array}{l}\text { Sonja A. } \\
\text { Rasmussen, } \\
\text { MD, MS, } \\
\text { Colleen F. } \\
\text { Kelley, MD, } \\
\text { MPH, John P. } \\
\text { Horton, MD, } \\
\text { and Denise J. } \\
\text { Jamieson, MD, } \\
\text { MPH.. }\end{array}$ & $\begin{array}{l}\text { Coronavirus } \\
\text { Diasease } 2019 \\
\text { (Covid-19) } \\
\text { Vaccines And } \\
\text { Pregnancy, What } \\
\text { Obstetricians } \\
\text { Need To Know }\end{array}$ & $\begin{array}{l}\text { The } \\
\text { American } \\
\text { College of } \\
\text { Obstetrician } \\
\mathrm{s} \\
\text { and } \\
\text { Gynecologis } \\
\text { ts }\end{array}$ & $\begin{array}{l}\text { Untuk } \\
\text { mengetah } \\
\text { ui apa saja } \\
\text { yang } \\
\text { harus } \\
\text { dokter } \\
\text { kandunga } \\
\text { n tau } \\
\text { mengenai } \\
\text { pemberian } \\
\text { vaksin } \\
\text { pada ibu } \\
\text { hami. }\end{array}$ & $\begin{array}{l}\text { Wanita hamil perlu } \\
\text { menggunakan data terbatas } \\
\text { yang tersedia untuk } \\
\text { mempertimbangkan } \\
\text { penggunaan vaksin yang } \\
\text { bermanfat atau berisiko } \\
\text { selama kehamilan. Selain itu } \\
\text { dokter kandungan harus } \\
\text { meninjau studi toksikologi } \\
\text { perkembangan han dan } \\
\text { reproduksi pada hewan } \\
\text { mengenai vaksin, karena } \\
\text { untuk saat ini uji klinis pada } \\
\text { manusia hamil masih belum } \\
\text { tersedia. }\end{array}$ \\
\hline
\end{tabular}

Dari rangkaian artikel-artikel diatas yang telah dianalisis, belum ada data konkrit terkait keamananya. Regulasi penggunaan darurat pada vaksin menjadi landasan pemberian vaksin, terlebih dengan kondisi pandemi yang sudah mencapai 200 juta kasus. Terlebih bagi ibu hamil, infeksi SARS-CoV-2 pada ibu hamil diantaranya menyebabkan morbiditas pada bayi baru lahir, seperti persalinan premature, gawat janin, gangguan pernapasan, trombositopenia disertai dengan fungsi hati yang abnormal, dan bahkan kematian. Namun, transmisi vertikal SARS-CoV-2 belum dapat dikonfirmasi secara klinis (Chang, Wu and Chang, 2020; Zhu et al.,) 2020). Oleh karena itu, vaksinasi memiliki kemungkinan tinggi untuk mencegah infeksi COVID-19 yang parah dan efek sampingnya 
pada pasien hamil dan neonatus mereka

(Chavan, et al : 2021)

Penggunaan vaksinisasi ini dilakukan

\section{DAFTAR PUSTAKA}

untuk mengurangi laju orang terinfeksi dan memaksa tubuh untuk membentuk antibodi sehingga, apabila terinfeksi COVID-19 gejala yang ditimbulkan akan lebih ringan. Meskipun demikian masih diperukan data-data ilmiah yang memastikan tidak adanya efek samping yang sistematik terhadap tubuh. Namun, dibalik itu manfaat vaksin lebih besar daripada resikonya. Vaksinasi COVID-19 pada ibu hamil dapat melindungi, melawan dan komplikasinya selama tahap awal kehamilan dan selama prakehamilan.

\section{KESIMPULAN}

Berdasarkan tinjauan di atas, pemberian vaksinisasi COVID-19 kepada wanita hamil dilakukan untuk menekan laju infeksi COVID19. Meskipun belum adanya uji klinis vaksin COVID-19 terhadap wanita hamil yang menyatakan keamanannya. Karena fisiologis orang hamil dengan orang yang tidak hamil berbeda, hal inilah yang membuat kekhawatiran apakah adanya efek samping yang merugikan bagi ibu ataupun janinnya. Terlepas dari hal itu manfaat vaksin lebih banyak daripada tingkat resikonya. Dan secara darurat pemerintah telah memberikan izin penggunaan vaksin bagi ibu hamil. Dengan demikian penelitian dan uji klinis masih harus tetap dilakukan terhadap pemberian vaksin COVID-19 bagi ibu hamil untuk mencegah efek samping yang lebih parah.

1. Briet, J., McAuliffe, FM., Baalman, JH. (2020). Is termination of early pregnancy indicated in women with COVID-19. Correspondence/European Journal of Obstetrics \& Gynecology and Reproductive Biology. 251:266284.

2. Chang, T., Wu, J. and Chang, L. (2020) 'Clinical characteristics and intrauterine vertical transmission potential of COVID-19 infection in nine pregnant women: a retrospective review of medical records', Journal of the Formosan Medical Association, (January), pp. 19-21.

3. Chavan M, Qureshi H, Karnati S, Kollikonda S. (2021) COVID-19 Vaccination in Pregnancy: The Benefits Outweigh the Risks. J Obstet Gynaecol Can. 2021 Jul;43(7):814-816. doi: 10.1016/j.jogc.2021.03.010. PMID: 34253304; PMCID: PMC8267012.

4. Gugus Tugas Percepatan Penanganan COVID-19 (2020) Data Peta Sebaran, Gugus Tugas Percepatan Penanganan COVID-19. Available at: https://covid19.go.id/peta-sebaran

5. Male, v. (2021) Are Covid-19 Vaccines Safe In Pregnancy?. Nat rev immunol 21,200-201 (2021. https://doi.org/10.1038? S41577-02100525-y

6. Qiao, J. (2020). What are the risks of COVID-19 infection in pregnant women? The Lancet, 395, 760-762. https://doi.org/10.1016/S01406736(20)30365-2.

7. Rasmussen SA, Kelley CF, Horton JP, Jamieson DJ. (2021) Coronavirus Disease 2019 (COVID-19) Vaccines and Pregnancy: What Obstetricians Need to Know. Obstet Gynecol. 2021 Mar 1;137(3):408-414. doi: 10.1097/AOG.0000000000004290. Erratum 
in: Obstet Gynecol. 2021 May 1;137(5):962. PMID: 33370015 ; PMCID: PMC7884084.

8. Riley LE. (2021) mRNA Covid-19 Vaccines in Pregnant Women. $N$ Engl J Med. 2021 Jun 17;384(24):2342-2343. doi: 10.1056/NEJMe2107070. PMID: 34133864; PMCID: PMC8220929.

9. Shimabukuro TT, Kim SY, Myers TR, et al.(2021) Preliminary findings of mRNA Covid-19 vaccine safety in pregnant persons. N Engl J Med 2021;384:2273-2282.

10. Staffort, Parchem, Sibai. The Coronavirus Disease 2019 Vaccine In Pregnancy: Risks, Benefits, And Recommendations. American Journal of Obstretrics and Gynecology. https://ncbi.nlm.nih.gov/. Accessed: 28 Agustus 2021)
11. WHO (2021) WHO Coronavirus Disease (COVID-19) Dashboard, WHO Health Emergency Dashboard. Available at: https://covid19.who.int/. (Accessed: 28 Agustus 2021).

12. Wikipedia (2021) Penyakit Coronavirus (COVID-19), Kasus baru dan kematian. Available at: https://en.m.wikipedia.org/ (Accessed: 28 Agustus 2021). 